\title{
Long Noncoding RNA HI9 Induces Neuropathic Pain by Upregulating Cyclin-Dependent Kinase 5-Mediated Phosphorylation of CAMP Response Element Binding Protein [Retraction]
}

\author{
Li K, Jiao Y, Ren X, You D, Cao R. J Pain Res. \\ 2020;13:2113-2124.
}

At the request of the authors, the Editor-in-chief and Publisher of Journal of Pain Research wish to retract the following article.

In the reported study the authors found that Long noncoding RNA H19 was highly expressed in the spinal dorsal horn after chronic constriction injury in rats, and the silencing of H19 could ameliorate neuropathic pain via the von Frey filament test. Recently, the authors performed another batch of experiments using the same neuropathic pain model, and knockdown of H19 by siRNA served as a positive control, which was supposed to inhibit neuropathic pain. However, the authors found that the silencing of H19 by the siRNA did not ameliorate the neuropathic pain and despite several attempts the behavioral test previously described could not be reproduced and the authors cannot clearly explain the reason for this. As they are unable to support their findings the authors wish to retract the published paper and the editor has agreed with this request.

Our decision-making was informed by our policy on publishing ethics and integrity and the COPE guidelines on retraction.

The retracted article will remain online to maintain the scholarly record, but it will be digitally watermarked on each page as "Retracted".

\section{Publish your work in this journal}

The Journal of Pain Research is an international, peer reviewed, open access, online journal that welcomes laboratory and clinical findings in the fields of pain research and the prevention and management of pain. Original research, reviews, symposium reports, hypothesis formation and commentaries are all considered for publication. The manuscript management system is completely online and includes a very quick and fair peer-review system, which is all easy to use. Visit http:// www.dovepress.com/testimonials.php to read real quotes from published authors. 